\title{
Dose Sewage Need to be Treated Seriously
}

\section{Dawen Gao*}

State Key Laboratory of Urban Water Resource and Environment, Harbin Institute of Technology, China

The traditional concept of domestic sewage treatment emphasized degradation of COD and removal of phosphorus and nitrogen from domestic sewage to meet the national discharged standards, such as GB 18918-2002 in China. In the process of domestic sewage treatment, external energy, materials and human resource must be consumed, and the secondary pollution is inevitable. For example, in the traditional nitrogen removal involves two processes, aerobic nitrification process needs aerator which drived by electrical energy; and anoxic denitrification process requires methyl alcohol addition as organic carbon source. Also in the denitrification process there is $\mathrm{N}_{2} \mathrm{O}$ emission responsible for greenhouse effect. The electricity generation also is accompanied by air pollution and $\mathrm{CO}_{2}$ emission.
Domestic sewage is misplaced resource, and it is now being regarded more as a resource than a waste. What can we get from sewage? The main contaminant organic matters will be biomass energy to transform to biofuel analogues such as $\mathrm{CH}_{4}$ from anaerobic digestion, to electricity from microbial fuel cell, etc. Nitrogen and phosphorus are the major elements of fertilizer and nitrogen in sewage can be good source for fertilizer rather than removed as $\mathrm{N}_{2}$. Phosphorus recovery receives lots attention for its non-renewable characteristic. Struvite crystallization is an effective method for high concentrations of nitrogen and phosphorus simultaneous recovery. Reclaimed sewage can be used for irrigation to save water resource. The domestic sewage has great potential for resource recovery instead of a traditional treatment.
*Corresponding author: Dawen Gao, Professor, State Key Laboratory of Urban Water Resource and Environment, Harbin Institute of Technology, China, Tel. 86451-86289185, 86-13936568283; E-mail: dawengao@gmail.com

Received October 19, 2013; Accepted October 29, 2013; Published November 05, 2013

Citation: Gao D (2013) Dose Sewage Need to be Treated Seriously. Hydro Current Res 4: e111. doi:10.4172/2157-7587.1000e111

Copyright: (c) 2013 Gao D. This is an open-access article distributed under the terms of the Creative Commons Attribution License, which permits unrestricted use, distribution, and reproduction in any medium, provided the original author and source are credited. 